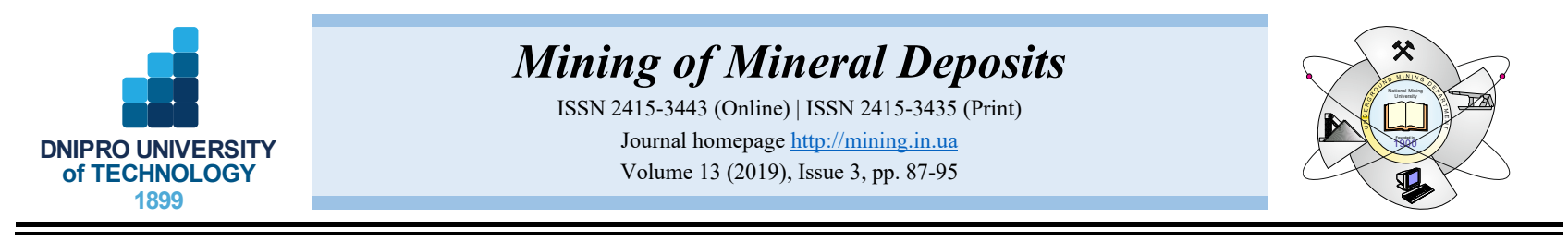

UDC 622.34

https://doi.org/10.33271/mining13.03.087

\title{
SELECTING A VARIANT TO ALLOCATE A PLANT PRODUCING SHOTCRETE WHILE IMPLEMENTING METHOD OF "WET" PNEUMATIC CONCRETE PLACING IN ORLOVSKAIA MINE
}

\author{
L. Krupnik ${ }^{1}$, Yu. Shaposhnik ${ }^{2}$, S. Shaposhnik ${ }^{3}$, A. Konurin ${ }^{2 *}$, D. Shokarev ${ }^{4}$ \\ ${ }^{1}$ Kazakh National Research Technical University named after K.I. Satpayev, Almaty, Kazakhstan \\ ${ }^{2}$ N.A. Chinakal Institute of Mining, Siberian Branch, Russian Academy of Sciences, Novosibirsk, Russian Federation \\ ${ }^{3}$ D. Serikbaev East-Kazakhstan State Technical University, Ust-Kamenogorsk, Kazakhstan \\ ${ }^{4}$ LLP “Expert PRO”, Ust-Kamenogorsk, Kazakhstan \\ *Corresponding author: e-mail anton.konurin@gmail.com,tel.+73832053030
}

\begin{abstract}
Purpose. Mining and geological conditions are complicated due to the decreased level of mining within deposits of West Kazakhstan. It results in significant increase in the amount of metal framed support which cannot always provide safety of mine workings. The problem may be solved by transition from heavy and labour-intensive in mounting metal special shape framed supports to the cheaper and more easily erected reinforced shotcrete with reinforced frames. "Dry" method of shotcrete application, used currently in Orlovskaia mine, can provide neither high quality nor the required amounts of pneumatic concrete placing; in this context, "wet" method makes it possible to support rock mass at a high mechanization level, and development of premium durable pavement. Thus, in the context of Orlovskaia mine it is required to solve the problems concerning selection of efficient schemes to deliver shotcrete mixtures or their components and to determine optimum location for a plant, producing shotcrete from the viewpoint of minimization of expenditures connected with shotcrete support.
\end{abstract}

Methods. Calculations, determining the required shotcrete amounts to support mine workings, technological capacity of a plant to produce shotcrete as well as self-propelled mixers, have been performed. Basic production facilities for shotcrete operations have been selected. Three variants to allocate a plant for shotcrete manufacturing within Orlovskaia mine have been considered. The discounted net cash flows have been compared ignoring sales of the finished product of Orlovskaia mine in terms of the available and the proposed methods to support mine workings for the period of $2016-2025$.

Findings. Relying upon laboratory tests, carried out in Kazzink LLP as well as BASF and Normet Companies, efficient compositions of shotcrete mixtures, providing preparation of shotcrete mixture of the required quality in terms of minimal binder consumption have been identified. It has been recommended to use $3.5 \mathrm{~m}^{3}$ mining machine UnimecMF500 Transmixer by Normet Company as a mixture to deliver shotcrete; self-propelled equipment MeycoME-3 (theoretical output is up to $20 \mathrm{~m}^{3} / \mathrm{h}$ ) by AtlasCopco Company has been proposed to apply "wet" shotcrete. Use of underground $15 \mathrm{~m}^{3} / \mathrm{h}$ mobile plant on stands or on trailer of Normet Company has been substantiated to be mounted in a small-cross chamber with cement bulk storage or in big bags. Schemes to allocate concrete mixing plant have been developed for specific conditions of Orlovskaia mine.

Originality. Specific features of potential variants to allocate a plant, producing shotcrete to support mine workings in terms of Orlovskaia mine, have been identified from technological and economic viewpoints.

Practical implications. Economic expediency of a process line intended to support mine workings in Orlovskaia mine using a "wet" shotcrete has been developed and substantiated.

Keywords: shotcreting, support of a mine working, transportation schemes, economic efficiency

\section{INTRODUCTION}

Recent analysis of injuries in underground mines has shown significant increase in the number of accidents while mine working driving and supporting. Selection of a support type in underground quarries is characterized by two problems. On the one hand, it is the decreased operational expenditures connected with supports; on the other hand, it is safe mining.

(C) 2019. L. Krupnik, Yu. Shaposhnik, S. Shaposhnik, A. Konurin, D. Shokarev. Published by the Dnipro University of Technology on behalf of Mining of Mineral Deposits. This is an Open Access article distributed under the terms of the Creative Commons Attribution License (http://creativecommons.org/licenses/by/4.0/),

which permits unrestricted reuse, distribution, and reproduction in any medium, provided the original work is properly cited. 
Shotcrete support has an impressive number of advantages: versatile construction, which can be applied as both temporary support, and permanent one while using independently and in combination with anchors, and reinforcing mesh. Its use helps decrease section of a mine working as well as amount of driving owing to the support thinning. In this context, the shotcrete layer operates as the integrated system with rock forming a structure of high carrying capability. Even thin layer of shotcrete prevents reliably rocks from destruction by external factors (mainly, oxygen action). As a result, rocks preserve their characteristics for a long time; at the same time, under usual conditions, rock strength may decrease by $60-70 \%$ in the course of time. High mechanization level of the supporting process increases labour productivity of shaftmen-timbermen twice or thrice (Barton, 2002; Balg, Roduner, \& Geobrugg, 2013; Shaposhnik, Konurin, Neverov, Neverov, \& Shaposhnik, 2016; Manin \& Mel'nikov, 2018).

\section{GEOTECHNOLOGICAL CONDITIONS OF ORLOVSKOE DEPOSIT MINING}

Orlovski polymetallic deposit in the East Kazakhstan is within the tectonic block confined by Berezovski overlap fault south-westerly and by Vostochny fracture submeridionally. The deposit is surrounded by granodiorite rock mass northerly (Volkov, Ginatulin, Sakharov, \& Chekalova, 1972). Mainly, ore-hosting rocks consist of: acid volcanics in a side wall; siliceous clayey aleurites with interlayers and lenses of volcanic rocks, volcanic ashes, and quartz-albitophyre tuffites in a lying wall. Frequent rock alternation is typical for the ore zone, i.e. lavas and lava-breccias of rhyolites, volcanic ashes, and acid tuffites as well as lavas of andesite-basalt composition.

The deposit is characterized by complex mining and geological conditions. Solid barite-polymetallic, copperzink, solid and quartzite embedded copper-sulphide ore as well as certain rock types are of high-strength and elastic characteristics. Hence, mine workings construction within the ores and rocks should involve dynamic manifestations of rock pressure. Rock rigidity decreases sharply within the areas of weathering, tectonic faults, and areas of hydrothermal variation of rocks which thickness varies from several meters up to $100-150 \mathrm{~m}$ (Krupnik, Shaposhnik, \& Shaposhnik, 2017). Wallrocks are rather unstable due to numerous multidirectional microfissures filled with calcite, pyrite, and multiply slipping planes.

Roadway construction within the cracked and fractured rock mass of Orlovski deposits should involve (Zhirnov, Abdrakhmanov, Shaposhnik, \& Konurin, 2018):

- rock mass injection methods;

- advance protective screens made of tubes;

- methods to fill in cavities and cave columns;

- monolithic concrete support;

- metal arch support;

- roof bolting;

- anchor cablebolts;

- shotcrete support inclusive of wet shotcreting.

Mining operations are concentrated within Yuzhnoe and Severnoe orebodies within 9-15 levels (Fig. 1).
The mine workings, constructed within the unstable rocks ( $4^{\text {th }}$ rigidity class) in Orlovskaia mine, are supported by means of SVP-22 using timber backfilling of cavities.

A line to manufacture SVP frame metal support operates in Orlovskaia mine. SVP-22 is delivered to Orlovski manufacturing complex in the form of linear segments. Rail-road cars with $60 \mathrm{t}$ total weight are applied. Almost $200 \mathrm{t}$ of SVP are delivered monthly. After unloading, SVP-22 is transported to a plant of production facilities under Orlovski manufacturing complex. Sets of clamp components for SVP-22 frames are manufactured at the territory of the plant of production facilities. A set of SVP22 frame consists of: two frame legs; two turning pieces; a roof beam; and three interframe tightening devices. Metal products to connect support elements are delivered separately. Eight metal products are used to assemble one SVP frame. Monthly delivery is almost 6000 pieces. Moreover, linear segments of embedded details, i.e. clamps to hold the packed timber along the mine working walls on SVP frames made of metal mountings with $32 \mathrm{~mm}$ diameter and $1.2 \mathrm{~m}$ length. One SVP frame needs four embedded details. Interval between SVP frame mounting is a meter. SVP frames are tightened by means of $2 \mathrm{~m}$ round timber. The round timber diameter is $16-22 \mathrm{~cm}$. Monthly timber delivery amount is almost $700 \mathrm{~m}^{3}$.

As a schedule list demonstrates, as for the construction and timbering operations in Orlovskaia mine, the amount of heavy SVP frame support has a steady tendency to its increase from 2016 to 2025 (Fig. 2). In 2016, the amount of frame support was 9.5 thousand pieces. In 2025, 19 thousand pieces are planned. Another situation is observed while planning shotcrete amounts. In 2016, the planned amounts were 30 thousand cubic meters of surface of mine workings to be shotcreted; in 2025, the figure will be 17 thousand cubic meters.

Increase in specific amount of metal frame supports can be explained by the worsened mining and geological conditions since mining operations are performed at lower levels inclusive of Severnoie orebody where wallrocks are rather fragmented and disintegrated. However, if enclosing rocks are unstable, it cannot always provide safety of mine workings even if double frames are mounted. Moreover, that worsens air supply as well as motion of self-propelled facilities due to the decreased finished cross-section.

Shotcrete support is applied both separately and in combination with other supports in $1^{\text {st }}, 2^{\text {nd }}, 3^{\text {rd }}$, and $4^{\text {th }}$ stability classes. Thickness of such a shotcrete mixture is no less than $3 \mathrm{~cm}$ for $1^{\text {st }}$ stability class; no less than $5 \mathrm{~cm}$ for $2^{\text {nd }}$ stability class; and $5-9 \mathrm{~cm}$ for $3^{\text {rd }}$ and $4^{\text {th }}$ classes (Instruktsiya po vyboru..., 2012).

Machine Meyco®Piccola and SB-67 are used to shotcrete mine workings. Dry ready shotcrete mixture MasterRoc ${ }^{\circledR}$ STS 1510, sifting, and cement are applied. Meyco ${ }$ Piccola machine is a device for shotcrete used for a dry mixture, and operating according to the rotary method (Pravila tekhnicheskoy ekspluatatsii, 1981). In future, Orlovskaia mine plans to apply three more shotcreting devices with pneumatic drive, i.e. Meyco®Piccolo020 LST. 


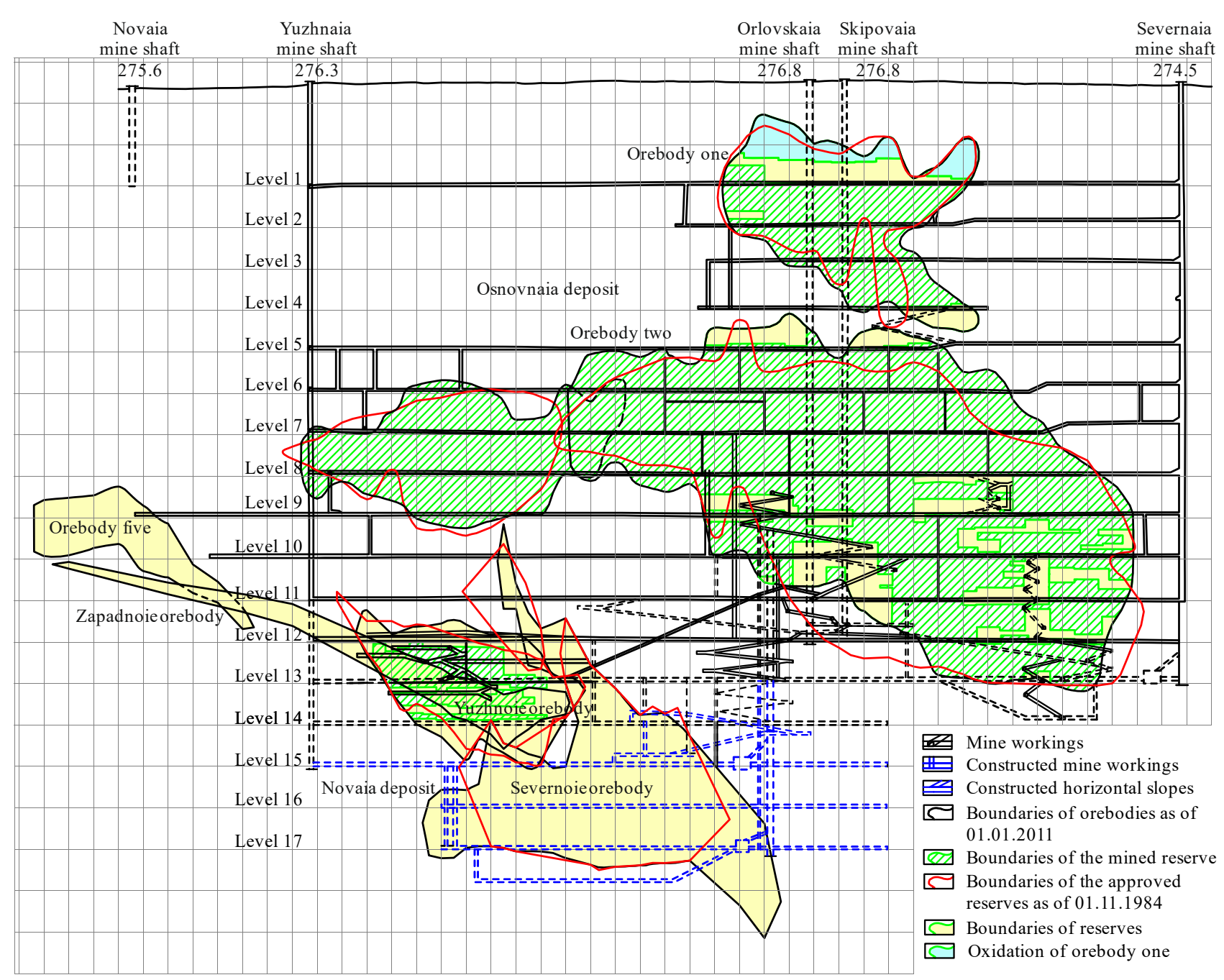

Figure 1. Opening scheme of Orlovski deposit

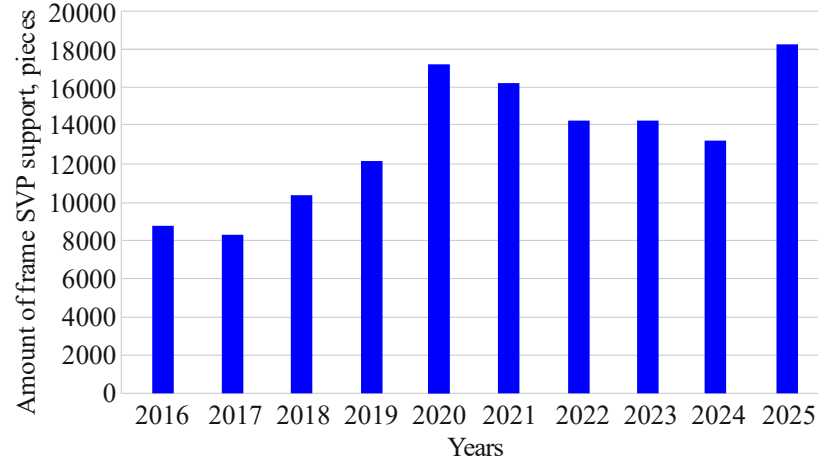

Figure 2. Diagrams of frame support amount increase in Orlovskaia mine during 2016 - 2025

\section{SUBSTANTIATING THE NECESSITY \\ TO APPLY WET SHOTCRETING TO \\ SUPPORT MINE WORKINGS AND CONCRETE PLANT CONSTRUCTION}

Geomechanical model of rock mass (Datacollection) has been developed according to the Standards by (ISRM).

Paper (Proekt organizatsii rabot, 2015) has classified rocks in terms of Q-rating, and additional types to timber mine workings have been recommended (depending upon a mine working spacing as well as a coefficient of mining conditions ESR):
- shotcreting $\left(1^{\text {st }}-4^{\text {th }}\right.$ classes in terms of Q-rating);

- roof bolting in certain areas $\left(1^{\text {st }}-6^{\text {th }}\right.$ classes $)$;

- regular anchoring together with fiber shotcre-ting $\left(4^{\text {th }}-8^{\text {th }}\right.$ classes $)$;

- regular anchoring by means of two-level anchors with cablebolts combined with fiber shotcreting $\left(6^{\text {th }}-8^{\text {th }}\right.$ classes);

- regular anchoring combined with $12-15 \mathrm{~cm}$ fiber shotcreting and reinforcement ribs $\left(7^{\text {th }}-9^{\text {th }}\right.$ classes $)$.

Wide and more flexible selection of support types makes it possible to reduce drastically expenses connected with timbering of mine workings while preserving labour safety.

Table 1 represents calculation results, concerning rock mass descriptions for lithological domains of Orlovski deposit. Following lithological types of rocks and ores of the deposit have been specified:

- Lithological code 1 -tufaceous silty sandstones, and siliceous aleurites;

- Lithological code 2 - albite porphyrites, and argillaceous-siliceous aleurites;

- Lithological code 3 -tufaceous silty sandstones, and ore impregnated metasomatites-chlorytolites;

- Ore code - copper-sulphide ore; solid polymetallic ore, solid copper-zinc ore, and impregnated copperpyritic ore within flinty aleurites. 
Table 1. Rock mass classification in terms of Q-rating by Barton

\begin{tabular}{lcccc}
\hline \multirow{2}{*}{\multicolumn{1}{c}{ Rock mass description }} & \multicolumn{5}{c}{$\begin{array}{c}\text { ithological domains } \\
\text { of Orlovski deposit }\end{array}$} \\
\cline { 2 - 5 } & 1 & 2 & 3 & Ores \\
\hline Exclusively soft, rather unstable & - & - & - & - \\
Extremely soft, rather unstable & - & - & - & - \\
Very soft, rather unstable & - & - & - & - \\
Soft, unstable & - & 2.15 & 1.02 & - \\
Medium stable & 4.72 & - & - & - \\
Hard, solid & - & - & - & 13.2 \\
Very hard, rather solid & - & - & - & - \\
Extremely hard, rather stable & - & - & - & - \\
Exclusively hard, rather stable & - & - & - & - \\
\hline
\end{tabular}

Hence, taking into account the classification of rocks in terms of Q-rating, timbering of mine workings within unstable enclosing rock may involve transition from metal frame supports, being heavy and labour-intensive from the viewpoint of mounting, to cheaper and less labour-intensive from technological viewpoint reinforced shotcrete with the reinforced frames when bearing capacity of supports is preserved. Table 2 demonstrates demand for shotcrete to support permanent mine workings as well as development ones for Orlovskaia mine taking into consideration extra coefficients relying upon the increased shotcrete consumption (VSN 126-90, 1991; RDS 82-202-96, 1996; ST TOO 050140000656-01-33.1, 2011a; Tekhnologicheskiy reglament (instruktsiya)..., 2016; Shaposhnik, Konurin, \& Shokarev, 2018).

Table 2. Demand for shotcrete to be used for timbering in Orlovskaia mine

\begin{tabular}{lcccccccccc}
\hline \multicolumn{1}{c}{ Year } & 2016 & 2017 & 2018 & 2019 & 2020 & 2021 & 2022 & 2023 & 2024 & 2025 \\
\hline $\begin{array}{l}\text { The required shotcrete } \\
\text { amount, } \mathrm{m}^{3} \text { per shift }\end{array}$ & 11.24 & 8.48 & 9.72 & 10.32 & 13.56 & 12.22 & 9.76 & 9.85 & 8.76 & 11.60 \\
$\begin{array}{l}\text { Time required for CMP } \\
\text { to prepare shotcrete per shift, } \mathrm{h}\end{array}$ & 2.05 & 2.77 & 2.45 & 2.29 & 1.43 & 1.79 & 2.44 & 2.41 & 2.70 & 1.95 \\
The required CMP capacity, $\mathrm{m}^{3} / \mathrm{h}$ & 5.45 & 3.06 & 3.96 & 4.50 & 9.48 & 6.82 & 4.00 & 4.08 & 3.24 & 5.94 \\
\hline
\end{tabular}

Currently, Orlovskaia mine uses "dry" shotcreting. In terms of Q-rating, for lithological domains of Orlovski deposit, shotcrete thickness should be $9-12 \mathrm{~cm}$ for unstable rocks, and $12-15 \mathrm{~cm}$ for rather unstable ones.

The equipment, operating in Orlovskaia mine, gives no way for the required shotcrete thickness and cannot provide necessary shotcreting amount. Thus, a decision was made to use $3.5 \mathrm{~m}^{3}$ mining machine UnimecMF500 Transmixer by Normet Company as a mixer to deliver shotcrete, and self-propelled unit MeycoME-3 by AtlasCopco Company for wet shotcreting. Its theoretical efficiency is $20 \mathrm{~m}^{3} / \mathrm{h}$.

Table 2 represents calculation results concerning the required time of operation of a plant to prepare shotcreting, using concrete mixing plant (CMP), and the required capacity of the CMP relying upon (ONTP 1-86, 1986).

Meka Company (Turkey), Putzmeister Company (Germany), and NormetCorporation Company (Finland) are the main world manufacturers of concrete/shotcrete plants for mining enterprises. A number of mining enterprises in the Russian Federation and CIS countries are experienced in the design and construction of surface and underground plants for concrete/shotcrete production.

In 2011, Nordgold Company almost implemented a project to construct concrete-stowing complex in Suzdal ore mine belonging to "Finansovo-investitsionnaia kompaniia "Alel". The project involved construction of a surface concrete plant in open pit 3. CMP consists of a horizontal single-shaft concrete mixer MB-30WS by Meka Company with $30 \mathrm{~m}^{3} / \mathrm{h}$ capacity completed with aggregate bunkers; $50 \mathrm{t}$ cement storage tank; batchers for cement, water, and admixtures; weight conveyor; pneumatic systems; automation systems; and control systems. Mine mixtures UNI 50-3 by Paus Company deliver the ready plastic stowing mixture to a receiving mine point using the main transportation mine workings up to a level being stowed; then concrete is delivered to the places where it should be laid by means of $125 \mathrm{~mm}$ pipeline using a concrete pump CJFA PC506/309 (Azel'khanov, Alibaev,
Zateeva, \& Alibaev, 2012). Oktiabrski ore mine of PJSC "MMC "Norilsk Nickel" uses automated mine concrete mini-plant BP $1504-2 / 8$ by Normet Company to manufacture shotcreting or structural concrete (Galaov, Nagovitsin, Pliev, Andreev, \& Vil'chinskiy, 2014; Uskov, Kondrat'yev, \& Neverov, 2017). Gayskiy MPC uses readymix station (RMS) operating at $1075 \mathrm{~m}$ level (Kalmykov, Volkov, Zubkov, Krasavin, \& Mikhaylova, 2015). The RMS construction at such a lower level has provided prompt delivery of concrete to working places which favours the improved labour productivity of staff of mine construction administration and the underground mine itself. Underground ready-mix station Minemix by Normet Company, which nominal capacity is $15 \mathrm{~m}^{3}$ of concrete per hour, has been mounted in Maleievski ore mine of Kazzink LLP. The station is complete equipment set for automated manufacturing of different concrete mixtures, inclusive shotcrete and ready mix, with potential to prepare cement mortar or special-quality concrete mixtures.

The major amount of shotcreting operations is planned within the area of mining operations intended to extract Severny ore body at the depths of $800-1200 \mathrm{~m}$ (the reserves have been taken to be projected down to $950 \mathrm{~m}$ depth, i.e. depth of level 18).

One of the key problems in the process of "wet" shotcreting method implementation in Orlovskaia mine is to select area and substantiate location of the shotcrete manufacturing plant to support mine workings from technological and economic viewpoints. Mixture composition (i.e. both scheme and productivity of ready mix delivery to operation area) and selection of the basic production equipment depend upon the plant location.

\section{SELECTING OPTIMAL LOCATION OF A PLANT TO MANUFACTURE SHOTCRETE USING A "WET" METHOD}

Concrete manufacturing plant location may involve following schemes: 
- within a mine site: mixture components are delivered to a warehouse near the plant. Ready mixture is transported to the mine by means of self-propelled mixtures or is delivered to the mine using wells;

- in a mine: mixture components are delivered by means of self-propelled transportation vehicles or to the mine using wells or an uphole.

Moreover, it is required to solve logistics problems while transporting, namely preparation and transportation of shotcreting mixtures as well as their components to working area or to a concrete plant.

Consider potential variants to locate the plant in Orlovskaia mine.

\subsection{Scheme 1}

Concrete mixing plant is located at the mine surface. Since in the near future mining operations will be performed within Severny orebody, assume that the plant is placed in the neighbourhood of concrete stowing complex (CSC) of Orlovskaia mine. Such a location advantages are as follows: closeness of surface inside CSC storages for nonreactive, expendable storage tanks of binding substances; availability of automobile service roads as well as railsides.

From CMP to the mine, shotcreting mixture is delivered using vertical flight of a pipeline (for instance, $159 \times 8 \times 8000$ st. 20 ). To do that, two wells (i.e. development well and recovery well) with casing are drilled from the surface down to level 15. In terms of such Severnaia mine mark as $+274.5 \mathrm{~m}$, and such level 15 mark as $-545.9 \mathrm{~m}$, depth of the wells will be almost $830 \mathrm{~m}$. Self-propelled mixers are loaded with shotcrete mixture through the charge capacity with a sliding gate (another design of the charge capacity is also possible) mounted within a lower share of the concrete-delivery pipeline at a height required for the mixer loading (for instance, it is $2900 \mathrm{~mm}$ depending upon a height of a charge capacity of such a mixer as Utimec MF 500 Transmixer).

Location of the loading node in the neighbourhood of joining conveyor mine working of level 15 (i.e. between Severny and Yuzhny orebodies within central part of mining operations) will help reduce expenditures connected with the transportation of shotcreting mixtures within the level. $240 \mathrm{~m}$ distance is from the projectable CMP location to 13 - 15 level slope (south); $70 \mathrm{~m}$ distance is to $15-16$ level slope (north); and $490 \mathrm{~m}$ distance is to a slope of 16 level (north).

Analysis of the calculations has shown that shotcreting at level 18 may result in $4.6 \mathrm{~m}^{3} / \mathrm{h}$ efficiency of PAUS UNI 50-3 mixer (its active capacity is $3.5 \mathrm{~m}^{3}$ ) in terms of the required maximal efficiency being $1.0 \mathrm{~m}^{3} / \mathrm{h}$. One mixer with $3.5 \mathrm{~m}^{3}$ active capacity and more and one shotcreting plant are quite sufficient to achieve target indicators. Minimal efficiency of industrial CMPs is $15 \mathrm{~m}^{3} / \mathrm{h}$; it is too few to provide complete equipment loa-ding. Practices of Oktiabrski ore mine of PJSC "MMC "Norilsk Nickel" have supported the idea to apply CMPs for shotcrete production as well as for the production of a ready mix for the enterprise needs (CMPs, considered below, can manufacture both shotcrete and ready mix).

\subsection{Scheme 2}

Concrete mixing plant is located at level 15 of the mine. It is recommended to use underground concrete mixing plant Minemix 15 by Normet Company or underground mobile plant with $15 \mathrm{~m}^{3} / \mathrm{h}$ efficiency. It is mounted either on legs or on a trailer to be erected within a small $16-25 \mathrm{~m}^{2}$ section chamber with big bag cement warehouse. CMP is in the neighbourhood of joining haulage roadway (Fig. 3).

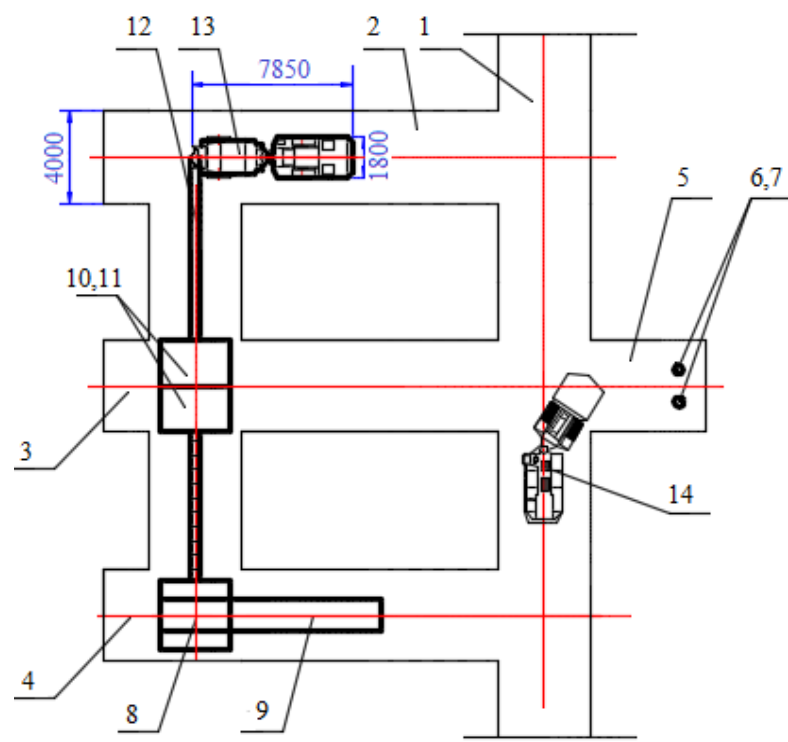

Figure 3. Scheme for CMP assembly and maintenance: 1 - joining haulage roadway; 2 - ort to load a mixer; 3 -ort to load inactive filler capacities; 4 -ort to load cement; 5 - pocket to reload sand and crushed rock; 6 and 7 -wells to transport latent solvents; 8 -tank for cement; 9 -frame crane; 10 and 11 capacities for sand and crushed rock; 12 - conveyor; 13 - mixer; 14 - self-propelled transloader (TL)

Inactive materials are delivered through development well or recovery well or through riser from surface to level 15 in the neighbourhood of CMP. Cement is delivered in $1.0-1.5 \mathrm{t}$ big bags using a shaft of Orlovskaia mine; it is delivered to CMP by means of self-propelled auxiliary equipment.

\subsection{Scheme 3}

Cement mixing plant is placed at level 12 of the mine (Fig. 4). It is recommended to use underground concrete mixing plant Minemix 15 by Normet Company or underground mobile plant with $15 \mathrm{~m}^{3} / \mathrm{h}$ efficiency. It is mounted either on legs or on a trailer to be erected within a small $16-25 \mathrm{~m}^{2}$ section chamber with big bag cement warehouse.

Inactive components of the mix are delivered through a shaft to level 10 of Orlovskaia mine: latent solvents are delivered in side dumpers which capacity is $2.5 \mathrm{~m}^{3}$; binding substances are delivered to level 12 in big bags. At level 12, the big bags with cement are transported to CMP using self-propelled equipment, for instance, in a bucket of LHD machine. By means of side-dump cars, sand and crushed rocks are delivered to a conveying raiser from level 10 to level 12 to Slepaia mine at level 10. Further, they are delivered through a conveying 
raiser thus developing the required amount of inactive within the raiser itself (thus, there is no necessity to drive extra horizontal mine workings at level 12 for a warehouse of inactive agents). It is recommended to deliver sand and crushed rock from level 10 to level 12 separately, which involves the need to drive extra raiser.

(a)

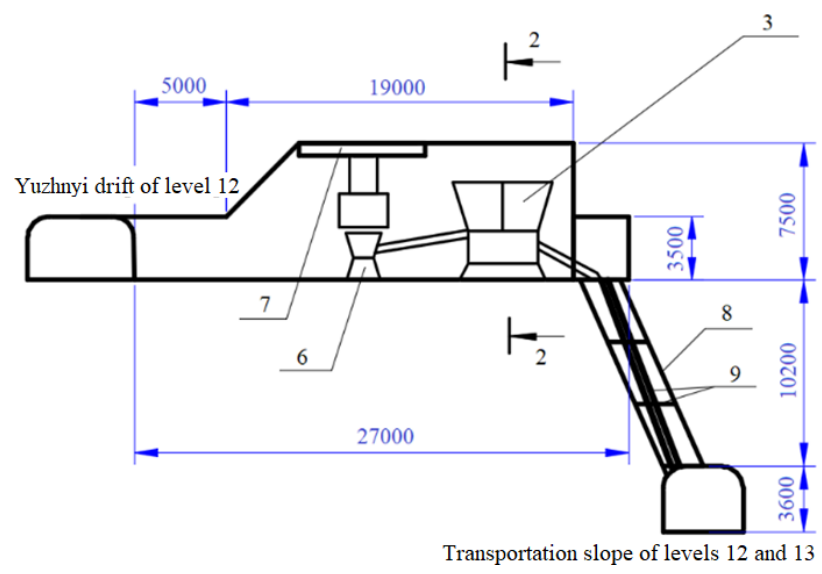

(b)

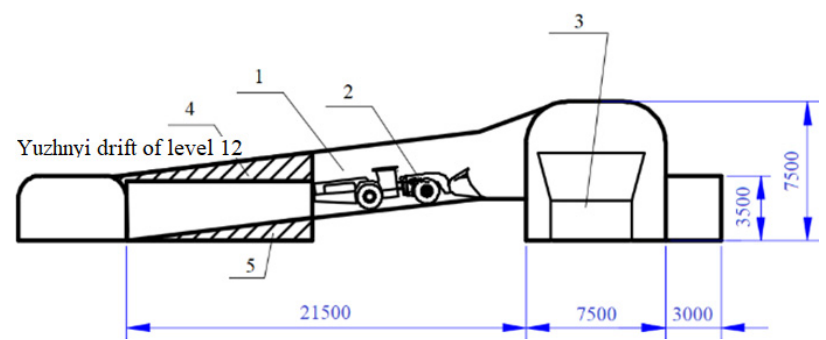

Figure 4. Scheme to place CMP at a level 12 in the neighbourhood of a conveying raiser from level 10 to a level 12: (a) general view; (b) sectional view 2-2; 1 -driveway 1 to CMP; $2-L H D$ machine; 3 -tank for sand, and crushed rock; 4-deroofing; 5-stowing; 6-tank for cement; 7 -telpher; 8 -raiser; $9-d=100$ mm pipe, 2 pieces

Length of extra mine workings, driven for CMP, is $69 \mathrm{~m}$ or $800 \mathrm{~m}^{3}$. The mine workings are timbered in a combined manner: shotcrete with mesh and steel polymeric roof bolting.

Taking into consideration the achievement of the required amount of shotcreting as well as higher efficiency of CMP, optimal location of shotcrete production plant in Orlovskaia mine is at level 12 in the neighbourhood of conveying raiser from level 10 to level 12 from the viewpoint of the shotcrete support cost minimization (Scheme 3).

\section{SUBSTANTIATING EFFICIENCY OF THE "WET" SHOTCRETING METHOD IMPLEMENTATION}

According to (VSN 126-90, 1991), minimal value of concrete compression strength should be B25; it is B22.5. according to (ST TOO 050140000656-01-33.1, 2011a; ST TOO 050140000656-01-33.1, 2011b). If concrete grade is B25, then average concrete compression strength should be $32.06 \mathrm{MPa}$ at the age of 28 days.
Relying upon the laboratory tests, Kazzink LLP has identified the balanced shotcrete composition providing production of shotcrete mixture of the required grade in terms of minimal consumption of a binding material, $\mathrm{kg} / \mathrm{m}^{3}$ : cement -440 ; water -190 ; sand -1150 ; and crushed rock -575 .

Mixtures, developed by BASF Tsentralnaia Azia Ltd and Normet Company for Orlovskaia mine, have been also taken as the balanced high-grade shotcrete composition for cement mixture with minimal binding material consumption. The mixtures include hardener, plastifier, and fiber.

Compositions of mixtures, recommended by BASF Tsentralnaia Azia Ltd, are follows:

- composition $1, \mathrm{~kg} / \mathrm{m}^{3}$ : cement - 400 - 430; sand 1644; crushed rock - 178; water - 168; and MasterGlenium ${ }^{\circledR} \mathrm{T} 803$ additive $-1.0-1.2 \%$. The mixture density is 2394;

- composition $2, \mathrm{~kg} / \mathrm{m}^{3}$ : cement - $400-430$; sand 1825; water - 168; and MasterGlenium ${ }^{\circledR}$ T 803 additive $1.0-1.2 \%$. The mixture density is 2394 .

Compositions of mixtures, recommended by Normet Company, are as follows:

- composition $1, \mathrm{~kg} / \mathrm{m}^{3}$ : PTs400D0N cement - 460; fine aggregate (i.e. sand) - 1030; coarse aggregate (i.e. crushed rock) - 670; TamCem 60 superplasticizer - 5.58; BarChip 54 fiber -3.0 ; water -210 . The mixture density is 2370 ;

- composition 2, $\mathrm{kg} / \mathrm{m}^{3}$ : PTs400D0N cement - 468; fine aggregate (i.e. sand) - 1038; coarse aggregate (i.e. crushed rock) - 678; TamCem 60 superplasticizer - 4.65; BarChip fiber 54 - 3.0; water - 208. The mixture density is 2400 .

The following should be mentioned among the key advantages of the "wet" shotcreting method applied in Orlovskaia mine:

- decrease in rebound and, as a result, two and more times decrease in losses;

- increase in productivity of shotcreting operations;

- improvement of labour productivity owing to intensive dust emission control;

- low compressed air demand while using hydraulic feeding of shotcreting mixture;

- decrease in shotcreting equipment deterioration;

- improvement of the applied shotcrete grade at the expense of water-cement ratio invariability.

Discounted net flows of real money in terms of the proposed method have been calculated with no consideration of commercial output sales when revenue is equal to zero (cost of the finished product of Orlovski industrial complex is not represented).

Analysis of the calculations of economic efficiency of the compared timbering alternatives has shown that in the context of Orlovskaia mine, a value of conditional NPV will be negative in terms of 0.3 discount rate. Thus, in terms of the available method (i.e. "dry" shotcreting method) it will be minus $=8627758$ thousand in 2025 . In terms of the proposed "wet" shotcreting method it will be T5355671 thousand. In the context of minimal cost, that means the efficiency of the proposed "wet" shotcreting method (Fig. 5). 


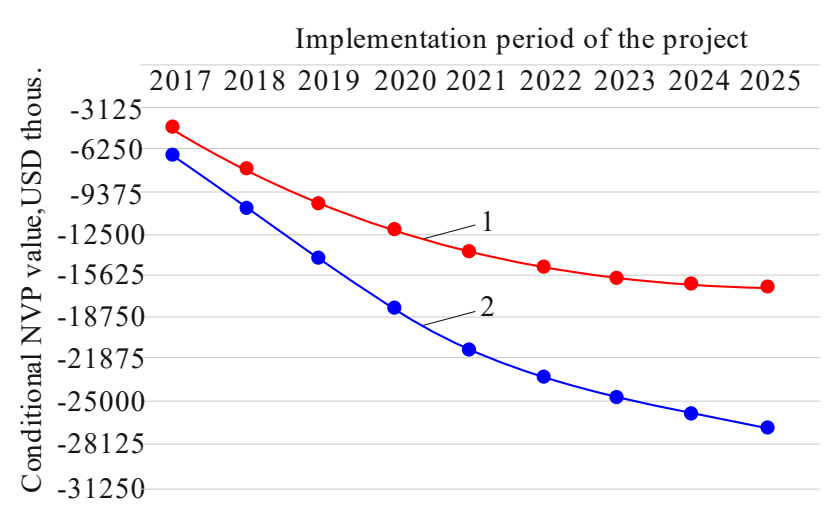

Figure 5. Comparison of the discounted net flows of real money with no consideration of commercial output sales by Orlovskaia mine in terms of the available method and the proposed one: 1 - the accumulated discount money flow in terms of 0.3 discount rate in the context of the proposed method; 2 -the accumulated discount money flow in terms of 0.3 discount rate in the context of the available method

Hence, the calculations have demonstrated economic efficiency of "wet" shotcrete method to compare with the "dry" method if frame supports are replaced in Orlovskaia mine.

\section{CONCLUSIONS}

Shotcrete support has impressive number of advantages owing to the decreased operational cost for timbering and safe mining.

Problems of the balanced schemes to transport shotcrete mixture as well as materials for its preparation have been considered for the conditions of Orlovskaia mine. Optimal allocation for a plant, manufacturing shotcrete, has been determined from the viewpoint of minimization of expenditures connected with shotcrete supports.

Calculations of the required shotcrete amount to support mine workings have been performed as well as selfpropelled mixers, and technological output of a plant to produce shotcrete. Basic manufacturing facilities have been selected. Three alternatives for shotcrete plant allocation in Orlovskaia mine have been considered. The discounted net money flows have been compared ignoring sales of the finished product of Orlovskaia mine in terms of the available and the proposed methods to support mine workings for the period of $2016-2025$.

Relying upon the laboratory tests, carried out by Kazzink LLP, and BASF and Normet Companies, the balanced compositions of shotcrete mixture, providing its high grade in terms of minimal consumption of a binding material, have been identified. It has been recommended to use $3.5 \mathrm{~m}^{3}$ mining machine UnimecMF500 Transmixer by Normet Company as a mixer to deliver shotcrete, and self-propelled equipment MeycoME-3 (theoretical output is up to $20 \mathrm{~m}^{3} / \mathrm{h}$ ) by AtlasCopco Company to apply "wet" shotcrete. Use of underground $15 \mathrm{~m}^{3} / \mathrm{h}$ mobile plant on stands or on trailer of Normet Company has been substantiated to be mounted in a small-cross chamber with cement bulk storage or in big bags. Schemes to allocate concrete mixing plant have been developed for specific conditions of Orlovskaia mine.

\section{ACKNOWLEDGEMENTS}

The authors express their sincere gratitude to engineering and technical personnel of Orlovskaia mine of Vostoktsvetmet ltd for assistance in organizing and conducting observations in mines.

\section{REFERENCES}

Azel'khanov, A.Zh., Alibaev, Zh.O., Zateeva, S.M., \& Alibaev, A.O. (2012). Tekhnologiya zakladochnykh rabot na rudnike "Suzdal'skiy". Gornyy Zhurnal Kazakhstana, (7), 24-26.

Balg, C., Roduner, A., \& Geobrugg, A. (2013). Ground support applications. In International Ground Support Conference (pp. 1-6). Krakow, Poland: AGH University.

Barton, N. (2002). Some new Q-value correlations to assist in site characterisation and tunnel design. International Journal of Rock Mechanics and Mining Sciences, 39(2), 185-216. https://doi.org/10.1016/s1365-1609(02)00011-4

Galaov, R.B., Nagovitsin, Yu.N., Pliev, B.Z., Andreev, A.A., \& Vil'chinskiy, V.B. (2014). Sovershenstvovanie sposobov krepleniya vyrabotok na rudnikakh ZF OAO "GMK "Noril'skiy nikel'”. Gornyy Zhurnal, (4), 25-28.

Instruktsiya po vyboru tipa $i$ parametrov krepi gornykh vyrabotok v usloviyakh Orlovskogo rudnika. (2012). Ust'Kamenogorsk, Kazakhstan: PO "Vostoktsvetmet".

Kalmykov, V.N., Volkov, P.V., Zubkov, A.A., Krasavin, A.V., \& Mikhaylova, G.V. (2015). Otsenka effektivnosti primeneniya mekhanizirovannykh kompleksov mokrogo nabryzgbetonirovaniya v usloviyakh stroitel'stva glubokikh gorizontov Gayskogo podzemnogo rudnika. Vestnik Nauki i Obrazovaniya Severo-Zapada Rossii, (3), 1-8.

Krupnik, L.A., Shaposhnik, Y.N., \& Shaposhnik, S.N. (2017). Experience in introduction of technology of filling of the domes with saponific resins at the mines of TOO Vostoktsvetmet. Occupational Safety in Industry, (7), 38-42. https://doi.org/10.24000/0409-2961-2017-7-38-42

Manin, Yu.A., \& Mel'nikov, A.E. (2018). Smesi MBV i opyt ikh primeneniya pri kreplenii podzemnykh gornykh vyrabotok. Innovatsionnye Geotekhnologii pri Razrabotke Rudnykh i Nerudnykh Mestorozhdeniy, 26-33.

ONTP 1-86. (1986). Normy tekhnologicheskogo proektirovaniya podzemnogo transporta gornodobyvayushchikh predpriyatiy. Moskva, Rossiya: Minuglepromom SSSR.

Pravila tekhnicheskoy ekspluatatsii rudnikov, priiskov $i$ shakht, razrabatyvayushchikh mestorozhdeniya tsvetnykh redkikh $i$ dragotsennykh metallov. (1981). Moskva, Rossiya: Nedra.

Proekt organizatsii rabot po torkretirovaniyu gornykh vyrabotok. (2015). Zhezkent, Kazakhstan: Orlovskiy proizvodstvennyy kompleks.

RDS 82-202-96. (1996). Pravila razrabotki $i$ primeneniya normativov trudnoustranimykh poter' $i$ otkhodov materialov v stroitel'stve. Moskva, Rossiya: Minstroy Rossii.

Shaposhnik, Y., Konurin, A., Neverov, S., Neverov, A., \& Shaposhnik, S. (2016). Justification of mine working supports in terms of the rating classification of Norwegian geotechnical institute. $16^{\text {th }}$ International Multidisciplinary Scientific GeoConference SGEM2016, Science and Technologies in Geology, Exploration and Mining, (2), 519-526. https://doi.org/10.5593/sgem2016/b12/s03.068

Shaposhnik, Yu.N., Konurin, A.I., \& Shokarev, D.A. (2018). Razrabotka tekhnologii krepleniya gornykh vyrabotok $\mathrm{v}$ usloviyakh intensivnogo okisleniya sul'fidnykh rud na Orlovskom mestorozhdenii. Vestnik RUDN. Seriya: Inzhenernye Issledovaniya, 19(2), 235-245.

ST TOO 050140000656-01-33.1. (2011a). Kreplenie gornykh vyrabotok na rudnikakh TOO "Korporatsiya Kazakhmys". Almaty, Kazakhstan: TOO "Korporatsiya Kazakhmys". 
ST TOO 050140000656-01-33.1. (2011b). Vybor sostava torkretbetona. Tekhnologicheskiy reglament. Almaty, Kazakhstan: TOO "Korporatsiya Kazakhmys".

Tekhnologicheskiy reglament (instruktsiya) po vyboru tipov, parametrov krepi $i$ tekhnologii ikh vozvedeniya na Orlovskom mestorozhdenii. (2016). Ust'-Kamenogorsk, Kazakhstan: TOO "Vostoktsvetmet".

Uskov, V.A., Kondrat'yev, S.A., \& Neverov, S.A. (2017). Ob ekonomicheskoy tselesoobraznosti otrabotki zapadnogo flanga medistykh rud Oktyabr'skogo mestorozhdeniya s porodnoy zakladkoy vtorichnykh kamer. Fiziko-Tekhni-cheskie Problemy Razrabotki Poleznykh Iskopaemykh, (6), 133-139.
Volkov, V.M., Ginatulin, A.M., Sakharov, I.T., \& Chekalova, K.A. (1972). Orlovskoe rudnoe pole na Rudnom Altae. AlmaAta, Kazakhstan: Nauka KazSSR.

VSN 126-90. (1991). Normy proektirovaniya i proizvodstva rabot nabryzgbetonom $i$ ankerami pri stroitel'stve transportnykh tonneley i metropolitenov. Moskva, Rossiya: Mintransstroy SSSR.

Zhirnov, A.A., Abdrakhmanov, S.U., Shaposhnik, Yu.N., \& Konurin, A.I. (2018). Otsenka ustoychivosti massiva gornykh porod i vybor tipa i parametrov krepleniya vyrabotok na Orlovskom polimetallicheskom mestorozhdenii. Gornyy Zhurnal, (3), 51-57.

\section{ВИБІР ВАРІАНТУ РОЗМІЩЕННЯ ЗАВОДУ 3 ВИРОБНИЦТВА ТОРКРЕТБЕТОНУ ПРИ ВПРОВАДЖЕННІ НА ОРЛОВСЬКІЙ ШАХТІ “МОКРОГО” МЕТОДУ ТОРКРЕТУВАННЯ}

\section{Л. Крупник, Ю. Шапошник, С. Шапошник, А. Конурін, Д. Шокарєв}

Мета. У зв'язку зі зниженням рівня гірничих робіт на родовищах східного Казахстану ускладнюються гірничо-геологічні умови. Наслідком цього $є$ значне зростання обсягів металевого рамного кріплення, яке не завжди гарантує збереження гірничих виробок. Вихід з ситуації, що склалася - це перехід від важких і трудомістких в установці металевих рамних кріплень зі спецпрофілю до дешевшого та технологічно більш легшеспоруджуваного армованого торкретбетону з армокаркасів. “Сухий” метод нанесення торкретбетону, що на сьогодні застосовується на Орловській шахті, не забезпечує високу якість та необхідні обсяги торкретування, при цьому технологія "мокрого" торкретбетонування дозволяє здійснювати роботи з кріплення гірського масиву з високим ступенем механізації і створенням високоякісного, довговічного покриття. У зв'язку з цим для умов Орловської шахти необхідно вирішити питання вибору раціональних схем транспортування торкретбетонної суміші або матеріалів для iї приготування, визначити оптимальне місце розташування заводу із приготування торкретбетону з точки зору мінімізації витрат на торкретбетонне кріплення.

Методика. Проведено розрахунок необхідного обсягу торкретбетону для кріплення виробок, технічної продуктивності заводу з виробництва торкретбетону, самохідних міксерів. Проведено вибір основного технологічного обладнання для виробництва торкретбетонних робіт. Розглянуто три варіанти розміщення заводу з виробництва торкретбетону на Орловській шахті. Проведено порівняння дисконтованих чистих потоків реальних грошей без урахування реалізації товарної продукції на Орловській шахті при існуючій технології кріплення гірничих виробок та тій, що пропонується на період 2016 - 2025 рр.

Результати. На підставі проведених лабораторних випробувань в TOO “Казцин", компаніях "BASF" i "Normet" визначені раціональні склади торкретбетонної суміші, що забезпечують отримання торкретбетонної суміші необхідної якості при мінімальних витратах в'яжучого. Рекомендовано в якості міксера для доставки торкретбетону застосовувати гірничо-шахтну машину Unimec MF500 Transmixer ємністю $3.5 \mathrm{~m}^{3}$ фірми "Normet", а в якості обладнання для напилення "мокрого" торкретбетону - самохідну установку для торкретирування Меусо ME-3 теоретичною продуктивністю 20 м³/год компанії "Atlas Copco". Обгрунтовано використання підземної мобільної установки продуктивністю 15 м³/год на стійках або на причепі фірми "Normet" для установки в камері малого перетину зі складом цементу в мішках біг-бег. Розроблено схеми розміщення бетонозмішувальної установки для конкретних умов Орловської шахти.

Наукова новизна. Встановлено особливості можливих варіантів розміщення заводу з виробництва торкретбетону для кріплення гірничих виробок для умов Орловської шахти з технологічної та економічної точок зору.

Практична значимість. Розроблено й обгрунтовано економічну доцільність технологічної лінії виробництва робіт щодо кріплення гірничих виробок “мокрим” торкретбетоном на Орловській шахті.

Ключові слова: торкретбетонування, кріплення гірничої виробки, схеми транспортування, економічна ефективність

\section{ВЫБОР ВАРИАНТА РАЗМЕЩЕНИЯ ЗАВОДА ПО ПРОИЗВОДСТВУ ТОРКРЕТБЕТОНА ПРИ ВНЕДРЕНИИ НА ОРЛОВСКОЙ ШАХТЕ “МОКРОГО” МЕТОДА ТОРКРЕТИРОВАНИЯ}

\section{Л. Крупник, Ю. Шапошник, С. Шапошник, А. Конурин, Д. Шокарев}

Цель. В связи с понижением уровня горных работ на месторождениях восточного Казахстана осложняются горно-геологические условия. Следствием этого является значительный рост объемов металлического рамного крепления, которое не всегда гарантирует сохранность горных выработок. Выход из сложившейся ситуации это переход от тяжелых и трудоемких в установке металлических рамных крепей из спецпрофиля к более дешевому и технологически более легковозводимому армированному торкретбетону с армокаркасами. Применяемый в настоящее время на Орловской шахте "сухой” метод нанесения торкретбетона не обеспечивает высокое качество и необходимые объемы торкретирования, при этом технология "мокрого" торкретбетонирования позволяет производить работы по креплению горного массива с высокой степенью механизации и созданием высококачественного, долговечного покрытия. В связи с этим для условий Орловской шахты необходимо решить вопросы выбора рациональных схем транспортирования торкретбетонной смеси или материалов для ее 
приготовления, определить оптимальное место расположения завода по приготовлению торкретбетона с точки зрения минимизации затрат на торкретбетонное крепление.

Методика. Проведен расчет необходимого объема торкретбетона для крепления выработок, технической производительности завода по производству торкретбетона, самоходных миксеров. Проведен выбор основного технологического оборудования для производства торкретбетонных работ. Рассмотрены три варианта размещения завода по производству торкретбетона на Орловской шахте. Проведено сравнение дисконтированных чистых потоков реальных денег без учета реализации товарной продукции на Орловской шахте при существующей и предлагаемой технологиях крепления горных выработок на период 2016 - 2025 гг.

Результаты. На основании проведенных лабораторных испытаний в ТОО “Казцинк”, компаниях “BASF” и "Normet” определены рациональные составы торкретбетонной смеси, обеспечивающие получение торкретбетонной смеси требуемого качества при минимальном расходе вяжущего. Рекомендовано в качестве миксера для доставки торкретбетона применять горно-шахтную машину Unimec MF500 Transmixer емкостью 3.5 м "Normet", а в качестве оборудования для напыления “мокрого" торкретбетона - самоходную установку для торкретирования Меусо ME-3 теоретической производительнстью 20 м³/ч компании “Аtlas Сорсо”. Обосновано использование подземной мобильной установки производительностью $15 \mathrm{~m} /$ ч на стойках или на прицепе фирмы “Normet" для установки в камере малого сечения со складом цемента в мешках биг-бэг. Разработаны схемы размещения бетоносмесительной установки для конкретных условий Орловской шахты.

Научная новизна. Установлены особенности возможных вариантов размещения завода по производству торкретбетона для крепления горных выработок для условий Орловской шахты с технологической и экономической точек зрения.

Практическая значимость. Разработана и обоснована экономическая целесообразность технологической линии производства работ по креплению горных выработок “мокрым” торкретбетоном на Орловской шахте.

Ключевые слова: торкретбетонирование, крепление горной выработки, схемы транспортирования, экономическая эффективность

\section{ARTICLE INFO}

Received: 7 June 2018

Accepted: 16 August 2019

Available online: 3 September 2019

\section{ABOUT AUTHORS}

Leonid Krupnik, Doctor of Technical Sciences, Professor of the Department of Mining and Metallurgical Machinery and Equipment, Kazakh National Research Technical University named after K.I. Satpayev, 22 Satpayev St, 050013, Almaty, Kazakhstan. E-mail: leonkr38@mail.ru

Yuriy Shaposhnik, Doctor of Technical Sciences, Senior Researcher of the Laboratory of Physical and Technical Geotechnology, N.A. Chinakal Institute of Mining, Siberian Branch, Russian Academy of Sciences, 54 Krasny Ave., 630091, Novosibirsk, Russian Federation. E-mail: shaposhnikyury@mail.ru

Sergey Shaposhnik, Doctor of Technical Sciences, Professor of the Department of Geomechanics and Mining, D. Serikbaev East-Kazakhstan State Technical University, 69 Protozanov St, 70004, Ust-Kamenogorsk, Kazakhstan. E-mail: shaposhniksergey@mail.ru

Anton Konurin, Candidate of Technical Sciences, Senior Researcher of the Laboratory of Physical and Technical Geotechnology, N.A. Chinakal Institute of Mining, Siberian Branch, Russian Academy of Sciences, 54 Krasny Ave., 630091, Novosibirsk, Russian Federation. E-mail: anton.konurin@gmail.com

Denis Shokarev, Mining Engineer of the LLP “Expert PRO”, 47 Protozanov St., 070004, Ust-Kamenogorsk, Kazakhstan. E-mail: denshok82@,mail.ru 